\title{
Race, Sex, and Pretrial Detention in Federal Court: Indirect Effects and Cumulative Disadvantage
}

\author{
Cassia Spohn ${ }^{*}$
}

\section{INTRODUCTION}

The goals of those who called for implementation of the Federal Sentencing Guidelines varied. Whereas liberals argued that structured sentencing practices would enhance fairness and hold judges accountable for their decisions, conservatives asserted that the reforms would lead to harsher penalties that eventually would deter criminal behavior. Reformers on both sides of the political spectrum, however, agreed that the changes were designed to curb discretion and reduce unwarranted disparity. Reflecting this, the Federal Sentencing Guidelines Manual states that one of the three objectives Congress sought to achieve in enacting the Sentencing Reform Act of 1984 was "reasonable uniformity in sentencing by narrowing the wide disparity in sentences imposed for similar criminal offenses committed by similar offenders."

Research on the federal sentencing process reveals that the primary predictors of sentence outcomes are legally relevant factors, especially the presumptive sentence and whether the offender received either a regular downward departure or a downward departure for providing substantial assistance. ${ }^{2}$ However, extralegal factors also play a role.

Professor of Criminology and Criminal Justice, Arizona State University; Ph.D., University of Nebraska-Lincoln.

1. U.S. SENTENCING GUIDELINES MANUAL ch. 1, pt. A, introductory cmt. (2008).

2. See generally U.S. SENTENCING COMM'N, FifTEEN YeARS OF Guidelines SENTENCING: An Assessment of How Well the Federal Criminal Justice System is Achieving the GoAls of Sentencing Reform (2004); Celesta A. Albonetti, Sentencing Under the Federal Sentencing Guidelines: Effects of Defendant Characteristics, Guilty Pleas, and Departures on Sentence Outcomes for Drug Offenses, 1991-1992, 31 L. \& SoC'Y REV. 789 (1997) [hereinafter Albonetti, Sentencing]; Celesta A. Albonetti, The Joint Conditioning Effect of Defendant's Gender and Ethnicity on Length of Imprisonment Under the Federal Sentencing Guidelines for Drug Trafficking/Manufacturing Offenders, 6 J. GENDER RACE \& JUST. 39 (2002) [hereinafter Albonetti, Joint Conditioning Effect]; Richard D. Hartley et al., Prosecutorial Discretion: An Examination of Substantial Assistance Departures in Federal Crack-Cocaine and Powder-Cocaine Cases, 24 JusT. Q. 382 (2007); David B. Mustard, Racial, Ethnic, and Gender Disparities in Sentencing: Evidence from the U.S. Federal Courts, 44 J.L. \& ECON. 285 (2001); Cassia Spohn, Sentencing Decisions in 
There is compelling evidence that both sentence outcomes and the likelihood of receiving downward departures are affected by the offender's race/ethnicity, ${ }^{3}$ the offender's sex, ${ }^{4}$ and the combination of the offender's race/ethnicity, the offender's sex, and other offender characteristics. $^{5}$

There also is evidence that federal sentence outcomes are affected by the offender's pretrial status: offenders who are detained prior to trial are sentenced more harshly than those who are released. ${ }^{6}$ One study, for example, examined sentence outcomes in three U.S. District Courts, finding that offenders who were in custody at the time of sentencing received significantly longer sentences than those who were released, net of the presumptive sentence, other legally relevant case characteristics, and offender characteristics. ${ }^{7}$ Further analysis revealed that pretrial detention increased the length of the sentence by more than one year for black offenders and by nearly six months for white offenders. Detention prior to sentencing, on the other hand, did not affect sentence length for Hispanic offenders.

The results of the federal sentencing research conducted to date raise the possibility that legally irrelevant offender characteristics - especially the race and sex of the offender-may have direct and indirect effects on sentence severity. The fact that sentence severity is affected by the race

Three U.S. District Courts: Testing the Assumption of Uniformity in the Federal Sentencing Process, 7 Just. Res. \& POL'Y 1 (2005); Ann Martin Stacey \& Cassia Spohn, Gender and the Social Costs of Sentencing: An Analysis of Sentences Imposed on Male and Female Offenders in Three U.S. District Courts, 11 BERKELEY J. CRIM. L. 43 (2006).

3. See generally Ronald. S. Everett \& Roger A. Wojtkiewicz, Difference, Disparity, and Race/Ethnic Bias in Federal Sentencing, 18 J. QuANTITATIVE CRIMINOLOGY 189 (2002); Kimberly Kempf-Leonard \& Lisa L. Sample, Have Federal Sentencing Guidelines Reduced Severity? An Examination of One Circuit, 17 J. QuantiTATIVE CRIMINOLOGY 111 (2001); Mustard, supra note 2; Lisa Pasko, Villain or Victim: Regional Variation and Ethnic Disparity in Federal Drug Offense Sentencing, 13 CRIM. JuST. POL'Y REV. 307 (2002); Darrell Steffensmeier \& Stephen Demuth, Ethnicity and Sentencing Outcomes in U.S. Federal Courts: Who Is Punished More Harshly?, 65 Am. Soc. ReV. 705 (2000). But see generally Chandra D. LaFrentz \& Cassia Spohn, Who Is Punished More Harshly in Federal Courts? The Interaction of Race/Ethnicity, Gender, Age, and Employment Status in the Sentencing of Drug Offenders, 8 JUST. RES. \& POL'Y 25 (2006).

4. See generally U.S. SENTENCING COMM'N, supra note 2; Albonetti, Sentencing, supra note 2; Albonetti, Joint Conditioning Effect, supra note 2; Everett \& Wojtkiewicz, supra note 3; Hartley et al., supra note 2; LaFrentz \& Spohn, supra note 3; Mustard, supra note 2; Stacey \& Spohn, supra note 2 .

5. See generally Albonetti, Sentencing, supra note 2; Albonetti, Joint Conditioning Effect, supra note 2; LaFrentz \& Spohn, supra note 3; Cassia Spohn \& Lisa L. Sample, The Dangerous Drug Offender in Federal Court: Intersections of Race, Ethnicity, and Culpability, CRIME \& DELINQ. (forthcoming 2009); Stacey \& Spohn, supra note 2.

6. See generally LaFrentz \& Spohn, supra note 3; Spohn, supra note 2; Stacey \& Spohn, supra note 2; Jawjeong Wu \& Cassia Spohn, Inter-District Disparity in Sentencing in Three U.S. District Courts, CRIME \& DELINQ. (forthcoming 2009).

7. See generally LaFrentz \& Spohn, supra note 3. 
and sex of the offender, as well as the offender's pretrial status, raises the possibility that offender race and sex may influence sentencing both directly and through their effects on pretrial detention. If black offenders and male offenders are more likely than white offenders and female offenders to be held in custody at the time of sentencing, and if pretrial custody results in longer sentences for offenders generally, the "detention penalty" will be greater for black offenders and male offenders than for white offenders and female offenders. If the race and sex of the offender also have direct effects on sentence severity, then the effects of these offender characteristics would be cumulative. Black offenders would receive more severe sentences than white offenders because of their race and also because they are more likely than whites to be held in custody prior to trial. Similarly, male offenders would receive more severe sentences than female offenders because of their sex and also because they are more likely than females to be held in custody prior to trial.

The purpose of this essay is to test these possibilities. Using data on offenders convicted of drug offenses in three U.S. District Courts, I examine the effect of offender race and offender sex on the likelihood of pretrial detention. I also attempt to determine if the predictors of pretrial detention vary for white offenders and black offenders. In order to test expectations regarding the indirect and cumulative effects of offender race and sex on sentence outcomes, I also estimate models of sentence length that include the offender's pretrial status as a control variable.

The next section of the essay discusses the Bail Reform Act of 1984. This is followed by a discussion of the research design and the results of the analysis.

\section{THE BAIL REFORM ACT OF 1984}

Pretrial detention decisions in federal courts are structured by the Bail Reform Act of $1984,{ }^{8}$ which permits judges to detain a defendant as a means of insuring the safety of the community and the appearance of the defendant in court. Section 3142(b) of the Act states that the defendant must be released on personal recognizance or unsecured personal bond unless the judicial officer determines "that such release will not reasonably assure the appearance of the person as required or will endanger the safety of any other person or the community."

8. 18 U.S.C. $\S \S 3141-3150$ (2006).

9. Id. $\S 3142(\mathrm{~b})$. 
Section 3142(g) specifies the factors that judges must take into consideration in making decisions regarding pretrial release or detention. These factors are: (1) the nature and circumstances of the offense charged, including whether the offense is a crime of violence or involves a narcotic drug; (2) the weight of the evidence against the defendant; (3) the history and characteristics of the defendant; and (4) the nature and seriousness of the danger to any person or the community that would be posed by the defendant's release. ${ }^{10}$ Factors included in "the history and characteristics" of the defendant are the defendant's "character, physical and mental condition, family ties, employment, financial resources, length of residence in the community, community ties, past conduct, history relating to drug or alcohol abuse, criminal history, and record concerning appearance at court proceedings. ..." Also included in this section is "whether, at the time of the current offense or arrest, the [defendant] was on probation, on parole, or on other release pending trial, sentencing, appeal, or completion of sentence for an offense under Federal, State, or local law ...."12

What is interesting about this is that many of the factors that judges are required to take into consideration in determining the defendant's release status are factors that judges generally are precluded from considering in determining the appropriate sentence. In accordance with congressional directive, the Guidelines state that the offender's race, sex, national origin, creed, religion, and socioeconomic status are never relevant to the determination of the sentence. ${ }^{13}$ Moreover, certain offender characteristics, including the offender's age, education and vocational skills, employment record, family ties and responsibilities, and community ties, are "not ordinarily relevant" in determining whether a departure is warranted. ${ }^{14}$ Like the offender's race and sex, then, these "not ordinarily relevant" factors have the potential to influence sentence severity through their effects on pretrial release decisions.

\section{RESEARCH DESIGN AND METHODS}

The data for this study are a subset of data collected for a study of charging and sentencing decisions in three U.S. District Courts: the District of Minnesota, the District of Nebraska, and the Southern District

\footnotetext{
10. Id. $\S 3142(\mathrm{~g})(1)-(4)$.

11. Id. $\S 3142(\mathrm{a})(3)(\mathrm{A})$.

12. $I d . \S 3142(\mathrm{~d})(3)(\mathrm{B})$

13. U.S. SENTENCING Guidelines Manual $\S 5 H 1.10$ (2008).

14. Id. at ch. 5, pt. H, introductory $\mathrm{cmt}$.
} 
of Iowa. The datafile includes detailed information on all offenders sentenced in these courts during fiscal year 1998, fiscal year 1999, and fiscal year $2000 .^{15}$ The original datafile included 1188 cases from Minnesota, 1027 cases from Nebraska, and 924 cases from Southern Iowa. For this study, I selected all cases involving black offenders and white offenders ${ }^{16}$ who were convicted of a drug trafficking offense involving powder cocaine, crack cocaine, methamphetamine, or marijuana. ${ }^{17}$ This resulted in a datafile with 1142 cases: 417 from the Southern District of Iowa, 410 from the District of Nebraska, and 315 from the District of Minnesota.

I use the data from these three district courts, rather than data from all district courts in the United States, for several reasons. The most important reason is that the publicly-available datafiles from the United States Sentencing Commission do not include information on the offender's pretrial status. Moreover, many of the independent variables used in the analysis - especially those measuring the offender's stakes in conformity - either are not included in the publicly-available datafiles (e.g., the offender's employment status) or are included but contain substantial amounts of missing data (e.g., the offender's marital status and number of dependent children). Because I had access to the presentence reports in these three district courts, I was able to collect data on the offender's pretrial status and stakes in conformity. In addition, there is mounting evidence that sentence outcomes vary significantly among the district courts. ${ }^{18}$ This calls into question the conclusions of studies of

15. I obtained the United States Sentencing Commission's Offender Datafile for each district for each year. This datafile contained detailed information on the offender, the case, and the sentence; it also included a unique identifier that was used to match the case to case files maintained by the district court. I supplemented the Offender Datafile with information contained in the Presentence Report and the Order of Judgment. From the case files, trained data collectors collected detailed data on the charges that were filed, the disposition of each charge, the terms of the plea agreement, and whether an amended judgment was filed. From the presentence reports, I collected data on offender characteristics that are not included in the Sentencing Commission's datafiles, including the offender's current marital status, the number of children that the offender had and the number that he/she was providing financial support for, the offender's substance abuse history, and whether the offender was under any type of criminal justice control at the time of his/her arrest.

16. I excluded Hispanic drug offenders because two-thirds of them were non-citizens and because ninety-five percent of the Hispanic non-citizens were detained before trial. As a result, I was unable to separately estimate a model of pretrial detention for Hispanic drug offenders. I also eliminated twenty-four cases involving offenders who were Asian or Native American.

17. There were only sixteen offenders convicted of a drug offense involving use of a communications facility and only seven convicted of drug possession.

18. See generally Paul J. Hofer et al., The Effect of the Federal Sentencing Guidelines on InterJudge Sentencing Disparity, 90 J. CRIM. L. \& CRIMINOLOGY 239 (1999); Brian D. Johnson et al., The Social Context of Guidelines Circumvention: The Case of Federal District Courts, 46 CRIMINOLOGY 737 (2008); Paula M. Kautt, Location, Location, Location: Interdistrict and Intercircuit Variation in Sentencing Outcomes for Federal Drug-Trafficking Offenses, 19 JUST. Q. 
federal sentencing decisions that use data aggregated across all district courts. ${ }^{19}$ As Weisselberg and Dunworth have noted, "it is extremely difficult and, perhaps, unhelpful to draw general, system wide conclusions about the effect of the guidelines upon the district courts." Because of these concerns, I use data from three relatively homogeneous U.S. District Courts and I control for the district in which the case was adjudicated.

\section{A. Dependent and Independent Variables}

Descriptive statistics for the dependent and independent variables are presented in Table 1. I present separate statistics for white and for black offenders. The primary dependent variable is whether the offender was held in custody before the sentencing hearing. Offenders who were released at the time of sentencing could have been released on their own recognizance, released on bail, released on restrictive conditions, or released on an unsecured bond; ${ }^{21}$ offenders who were in custody prior to trial may have been denied bail or offered financial bail, but were unable to pay. As shown in Table 1, 53.3\% of these drug offenders were in custody at the time of the sentencing hearing.

633 (2002); Chantale LaCasse \& A. Abigail Payne, Federal Sentencing Guidelines and Mandatory Minimum Sentences: Do Defendants Bargain in the Shadow of the Judge?, 42 J.L. \& ECoN. 245 (1999); Spohn, supra note 2.

19. These studies assume, either explicitly or implicitly, that there is little inter-district variation in case processing policies and procedures and that findings regarding sentence outcomes at the national level therefore reflect the reality of decision making in each of the U.S. District Courts. Although it is certainly true that decision-makers in the federal criminal justice system are guided by a more uniform set of statutes and policies than those in the states, it does not necessarily follow that this will eliminate inter-district disparity or produce national uniformity in sentencing. Like courts at the state level, U.S. District Courts may differ on a number of dimensions (i.e., caseload, the type and seriousness of cases on the docket, rate of downward departures, or policies instituted by the U.S. Attorney regarding such things as departures for substantial assistance) and these differences may influence case processing procedures and case outcomes.

20. Charles D. Weisselberg \& Terence Dunworth, Inter-District Variation Under the Guidelines: The Trees May Be More Significant that the Forest, 6 FED. SENT'G REP. 25,27 (1993).

21. See generally U.S. Dep'T Of Justice, BuREau of Justice Statistics, SPeCial RePORT: FEDERAl PRETRial RELEASE AND DETENTION, 1996 (1999). 
Table 1: Dependent and Independent Variables: Codes and Frequencies Variables

Code

Total

Black

White

\begin{tabular}{llllllll} 
& \multicolumn{8}{c}{$\mathbf{N}$} & $\mathbf{\%}$ & $\mathbf{N}$ & $\mathbf{\%}$ & $\mathbf{N}$ & $\mathbf{\%}$ \\
\hline \multicolumn{7}{c}{ Dependent Variable } \\
In Custody $^{* \dagger}$ & $1=$ yes & 609 & 53.3 & 298 & 67.7 & 311 & 44.3 \\
& $0=$ no & 533 & 46.7 & 142 & 32.3 & 391 & 55.7
\end{tabular}

Independent Variables

\section{Offender's}

race/ethnicity

Black

White $^{\dagger}$

Offender's sex ${ }^{*}$

Offender's Age (mean in years)
$440 \quad 38.5$

$702 \quad 61.5$

$\begin{array}{llllll}223 & 19.5 & 63 & 14.3 & 160 & 22.8\end{array}$

$\begin{array}{llllll}919 & 80.5 & 377 & 85.7 & 542 & 77.2\end{array}$

29.69

34.59

\begin{tabular}{|c|c|c|c|c|c|c|c|}
\hline \multicolumn{8}{|c|}{ Indicators of Dangerousness } \\
\hline \multirow{2}{*}{$\begin{array}{l}\text { Prior Drug } \\
\text { Trafficking } \\
\text { Conviction }\end{array}$} & $1=$ yes & 357 & 31.3 & 194 & 44.1 & 163 & 23.5 \\
\hline & $0=$ no & 785 & 68.7 & 246 & 55.9 & 539 & 76.8 \\
\hline \multirow{2}{*}{$\begin{array}{l}\text { Use of a Weapon } \\
\text { during Offense }\end{array}$} & $1=$ yes & 256 & 22.4 & 109 & 24.8 & 147 & 20.9 \\
\hline & $0=$ no & 886 & 77.6 & 331 & 75.2 & 555 & 79.1 \\
\hline \multirow{2}{*}{ Under CJ control $^{*}$} & $1=$ yes & 440 & 38.5 & 223 & 50.7 & 217 & 30.9 \\
\hline & $0=$ no & 702 & 61.5 & 217 & 49.3 & 485 & 69.1 \\
\hline \multicolumn{8}{|c|}{ Indicators of Stakes in Conformity } \\
\hline
\end{tabular}

Offender's

education level*

\begin{tabular}{|c|c|c|c|c|c|c|c|}
\hline $\begin{array}{l}\text { No High School } \\
\text { Degree }^{\dagger}\end{array}$ & & 364 & 31.9 & 178 & 40.5 & 186 & 26.5 \\
\hline $\begin{array}{l}\text { High School } \\
\text { Degree Only }\end{array}$ & & 559 & 48.9 & 186 & 42.3 & 373 & \\
\hline $\begin{array}{l}\text { Some College/ } \\
\text { College Degree }\end{array}$ & & 219 & 19.2 & 76 & 17.2 & 143 & \\
\hline ffender's & 1=employed & 639 & 58.3 & 201 & 47.9 & 438 & 4.8 \\
\hline mployment status ${ }^{*}$ & $0=$ unemployed & 457 & 41.7 & 219 & 49.8 & 238 & 5.2 \\
\hline ffender's marital & $1=$ married & 224 & 19.8 & 75 & 17.2 & 149 & \\
\hline tatus & $0=$ unmarried & 909 & 80.2 & 361 & 82.8 & 548 & \\
\hline
\end{tabular}




\begin{tabular}{|c|c|c|c|c|c|c|c|}
\hline \multirow[t]{2}{*}{ Variables } & \multirow[t]{2}{*}{ Code } & \multicolumn{2}{|c|}{ Total } & \multicolumn{2}{|c|}{ Black } & \multicolumn{2}{|c|}{ White } \\
\hline & & $\mathbf{N}$ & $\%$ & $\mathbf{N}$ & $\%$ & $\mathbf{N}$ & $\%$ \\
\hline $\begin{array}{l}\text { Number of children } \\
(\text { mean })^{*}\end{array}$ & & \multicolumn{2}{|c|}{1.85} & \multicolumn{2}{|c|}{2.31} & \multicolumn{2}{|c|}{1.57} \\
\hline \multicolumn{8}{|c|}{ Access to Financial Resources } \\
\hline \multirow{2}{*}{ Private Attorney* } & $1=$ yes & 325 & 28.9 & 106 & 24.8 & 219 & 31.9 \\
\hline & $0=$ no & 798 & 71.1 & 322 & 75.2 & 476 & 68.5 \\
\hline \multicolumn{8}{|c|}{ Criminal History and Crime Seriousness } \\
\hline $\begin{array}{l}\text { Final criminal } \\
\text { history category } \\
(\text { mean })^{*}\end{array}$ & & \multicolumn{2}{|c|}{2.82} & \multicolumn{2}{|c|}{3.33} & \multicolumn{2}{|c|}{2.50} \\
\hline $\begin{array}{l}\text { Final offense level } \\
(\text { mean })^{*}\end{array}$ & & \multicolumn{2}{|c|}{27.55} & \multicolumn{2}{|c|}{29.48} & \multicolumn{2}{|c|}{26.34} \\
\hline \multicolumn{8}{|l|}{$\begin{array}{l}\text { Type of drug } \\
\text { offense }\end{array}$} \\
\hline Powder cocaine & & 133 & 11.6 & 54 & 12.3 & 79 & 11.3 \\
\hline Crack cocaine $^{\dagger}$ & & 376 & 32.9 & 357 & 81.1 & 19 & 2.7 \\
\hline Methamphetamine & & 553 & 48.4 & 19 & 4.3 & 534 & 76.1 \\
\hline Marijuana & & 80 & 7.0 & 10 & 2.3 & 70 & 10.0 \\
\hline \multicolumn{8}{|c|}{ District Court ${ }^{*}$} \\
\hline Minnesota & & 315 & 27.5 & 166 & 37.3 & 149 & 21.2 \\
\hline Nebraska & & 410 & 35.9 & 127 & 28.9 & 283 & 40.3 \\
\hline Southern Iowa & & 417 & 36.5 & 147 & 33.4 & 270 & 38.5 \\
\hline
\end{tabular}

The offender characteristics included in the model conform to the criteria set forth in the Bail Reform Act of 1984: the offender's dangerousness, community ties/stakes in conformity, the offender's access to financial resources, the offender's criminal history, and the seriousness of the crime. The offender characteristics are the offender's race $($ black $=1$; white $=0)$, sex $($ male $=1$; female $=0)$, and age (a continuous variable), three indicators of offender dangerousness/threat, and four indicators of the offender's community ties or stakes in conformity. The measures of dangerousness/threat include whether the offender had a prior drug trafficking conviction (yes $=1$; no $=0$ ), whether the offender used or possessed a weapon during the commission of the current offense (yes $=1$; no $=0$ ), and whether the offender was under the control of the criminal justice system at the time of the offense 
$($ yes $=1 ;$ no $=0) .^{22}$ The measures of stakes in conformity include the offender's education level, employment status (employed $=1$; unemployed $=0$ ), marital status (married $=1$; unmarried $=0$ ), and number of dependent children. Education is measured by three dummy variables (no high school degree, high school degree only, some college or college degree; some college/college degree is the reference category). Because the data file did not include information on the offender's income, I use the type of attorney representing the offender (private attorney $=1$; public defender or court-appointed attorney $=0$ ) as a proxy for access to financial resources. ${ }^{23}$

I also control for the offender's prior record and for the seriousness of the offense. Prior record is measured as the offender's final criminal history category ${ }^{24}$ and the seriousness of the offense is measured as the final offense level. ${ }^{25}$ Additional controls are included for the type of drug, which is measured by four dummy variables (powder cocaine, crack cocaine, methamphetamine, and marijuana; marijuana is the reference category), and the jurisdiction in which the case was adjudicated, which is measured by three dummy variables (Southern Iowa, Minnesota, and Nebraska; Southern Iowa is the reference category).

\section{B. Analytic Procedures}

The dependent variable for this study is a dichotomous indicator of whether the offender was in custody before trial. I therefore analyzed the data using binary logistic regression. Two separate models were estimated in order to identify the factors that predict whether an offender was released or held in custody prior to or at the time of sentencing (Table 2) and to determine if the effects of the predictors vary for white

22. Offenders under criminal justice control at the time of the offense are those who were on probation, supervised release, work release furlough, bond, in jail or prison, an escapee, or who had active warrants.

23. See Charles M. Katz \& Cassia C. Spohn, The Effect of Race and Gender on Bail Outcomes: A Test of an Interactive Model, 19 AM. J. CRIM. JUST. 161 (1995).

24. The criminal history score ranges from one (no criminal history points) to six (thirteen or more criminal history points). Although this score is not calculated until later in the process, judges at the bond hearing have access to information concerning the offender's criminal history. The criminal history score is a summary of this information.

25. The final offense level reflects the base severity score for the crime committed (which ranges from one to forty-three), adjusted for specific offense characteristics (e.g., the amount of drugs for which the offender will be held accountable), and other specified factors (e.g., the offender's role in the offense, the vulnerability of the victim, whether the offender obstructed justice, and whether the offender pled guilty in a timely manner). Like the criminal history score, the final offense level is a summary measure. 
offenders and black offenders (Table 3). Race-specific models were created by partitioning the data by race and then re-estimating the model.

In order to test the expectations regarding the indirect and cumulative effects of offender race, I also estimated a model of sentence length (Table 4), which is measured by the prison sentence imposed on the offender, in months. This model controlled for the offender's pretrial status and most of the other variables included in the model of pretrial status. There are, however, some differences in the variables included in the two models. Whereas the model of pretrial status included the offender's final criminal history category and final offense level, the model of sentence length included the presumptive sentence, which is the approach recommended by the United States Sentencing Commission. ${ }^{26}$ The presumptive sentence, which is based on the offense seriousness score and the criminal history score, is the minimum sentence that the judge could impose without departing from the Guidelines. In order to account for mandatory minimum sentences that were prevalent in drug cases, the presumptive sentence was measured as the Guideline minimum unless a mandatory minimum sentence was triggered and indicated a longer sentence than the Guideline minimum. In such cases, the presumptive sentence was measured as the mandatory minimum sentence. If there was a mandatory minimum sentence but the safety valve was applied, the presumptive sentence was the Guideline minimum. In estimating the sentence length model, I also included whether the offender received a regular downward departure (yes $=1$; no $=0$ ) or a downward departure for providing substantial assistance (yes $=$ $1 ;$ no $=0)$, and whether the offender pled guilty (yes $=1 ;$ no $=0$ ).

\section{FINDINGS}

The descriptive data presented in Table 1 illustrate that black offenders were significantly more likely than white offenders to be in custody at the time of sentencing: $67.7 \%$ of the black offenders, but only $44.3 \%$ of the white offenders, were in custody when the sentence was imposed. Table 1 also reveals, however, that with only one exception (use of a weapon during the offense), there are significant differences between black offenders and white offenders on all of the variables relevant to pretrial detention decisions. Black offenders were substantially more likely than white offenders to have a prior drug

26. See generally Rodney L. Engen \& Randy R. Gainey, Modeling the Effects of Legally Relevant and Extralegal Factors Under Sentencing Guidelines: The Rules Have Changed, 38 CRIMINOLOGY 1207 (2000). 
trafficking conviction or to have been under the control of the criminal justice system at the time of the offense. White offenders were significantly more likely than black offenders to have community ties (as measured by education, employment status, marital status) and access to financial resources (as measured by representation by a private attorney), but black offenders had more dependent children than white offenders. Black offenders also had higher criminal history scores and offense seriousness scores than did white offenders. These findings suggest that racial differences in the likelihood of pretrial detention could be due to racial differences in the criteria that judges can legitimately take into account in making decisions regarding bail and pretrial detention.

\section{A. Analysis of Pretrial Detention}

The data presented in Table 2, which displays the results of the logistic regression analysis using the full sample, indicate that both the race and the sex of the offender have a significant effect on the likelihood of pretrial detention, net of the offender's dangerousness, community ties, financial resources, criminal history, and crime seriousness. Black offenders were significantly more likely than white offenders to be held in custody prior to sentencing, and male offenders faced significantly higher odds of detention than did female offenders. Other predictors of the likelihood of pretrial detention include one of the three indicators of the offender's dangerousness and three of the four indicators of the offender's community ties. Offenders who were under the control of the criminal justice system at the time of the offense had higher odds of pretrial detention than did offenders who were not under the control of the system. The likelihood of pretrial detention was higher for offenders without a high school degree or with a high school degree only than for offenders with at least some college; it was lower for offenders who were employed and for offenders who were married. As expected, there was a significant positive relationship between the offender's criminal history score and pretrial detention and between the offense seriousness score and pretrial detention. The odds of pretrial detention also were affected by the type of drug involved in the offense (offenders charged with offenses involving powder cocaine were more likely to be in custody than those charged with offenses involving crack cocaine) and the district in which the case was adjudicated (offenders adjudicated in Minnesota and Nebraska were less likely than those adjudicated in Southern Iowa to be held in pretrial detention). 
Table 2: Logistic Regression Results: Likelihood of Pretrial Detention-Full Sample

\begin{tabular}{|c|c|c|c|}
\hline Variables & $\boldsymbol{b}$ & SE & Odds \\
\hline Offender's Race (black) & $.57^{*}$ & .28 & 1.77 \\
\hline Offender's Sex (male) & $.78^{*}$ & .19 & 2.18 \\
\hline Offender's Age & -.004 & .01 & 0.99 \\
\hline \multicolumn{4}{|c|}{ Indicators of Dangerousness } \\
\hline Prior Drug Trafficking Conviction & .12 & .18 & 1.13 \\
\hline Use of a Weapon During Offense & .13 & .18 & 1.14 \\
\hline Under Criminal Justice Control & $.48^{*}$ & .17 & 1.62 \\
\hline \multicolumn{4}{|c|}{ Indicators of Stakes in Conformity } \\
\hline \multicolumn{4}{|l|}{ Education } \\
\hline No High School Degree & $.60^{*}$ & .22 & 1.82 \\
\hline High School Degree Only & $.61^{*}$ & .21 & 1.83 \\
\hline \multicolumn{4}{|l|}{ Some College/College Degree ${ }^{\dagger}$} \\
\hline Offender Employed & $-.77^{*}$ & .16 & 0.46 \\
\hline Offender Married & $-.80^{*}$ & .19 & 0.45 \\
\hline Number of Children & .08 & .05 & 1.08 \\
\hline \multicolumn{4}{|c|}{ Access to Financial Resources } \\
\hline Private Attorney & -.09 & .17 & 0.92 \\
\hline \multicolumn{4}{|c|}{ Criminal History and Offense Seriousness } \\
\hline Final Criminal History Category & $.33^{*}$ & .06 & 1.39 \\
\hline Final Offense Level & $.08^{*}$ & .02 & 1.08 \\
\hline \multicolumn{4}{|l|}{ Type of Drug } \\
\hline \multicolumn{4}{|l|}{ Crack Cocaine ${ }^{\dagger}$} \\
\hline Powder Cocaine & $.73^{*}$ & .32 & 2.07 \\
\hline Methamphetamine & .17 & .31 & 1.19 \\
\hline Marijuana & .48 & .41 & 1.61 \\
\hline \multicolumn{4}{|c|}{ District Court } \\
\hline \multicolumn{4}{|l|}{ Southern Iowa $^{\dagger}$} \\
\hline Minnesota & $-.82^{*}$ & .20 & 0.44 \\
\hline Nebraska & $-.69^{*}$ & .18 & 0.50 \\
\hline Constant & $-3.64^{*}$ & .65 & \\
\hline \multicolumn{4}{|l|}{ Nagelkerke $\mathrm{R}^{2}=.38$} \\
\hline \multicolumn{4}{|l|}{${ }^{\dagger}$ reference category } \\
\hline${ }^{*} \mathrm{P} \leq .05$ & & & \\
\hline
\end{tabular}


The results discussed thus far indicate that an offender's pretrial status is predicted by a mix of legally relevant factors (i.e., crime seriousness and criminal history) and legally irrelevant offender characteristics (i.e., race and sex). The data presented in Table 3, which displays the results of the analysis using the data partitioned by the race of the offender, reveal that there are both similarities and differences in the factors that affect the likelihood of pretrial custody. The offender's sex, for example, affects pretrial custody for both black offenders and white offenders: pretrial detention was less likely for black females than for black males and for white females than for white males. Other factors that affect pretrial detention for both black offenders and white offenders are the offender's marital status, final criminal history category, final offense level, and the district in which the case was adjudicated. Moreover, Z-tests revealed that the effects of these offender and case characteristics on pretrial detention did not vary for black offenders and white offenders. ${ }^{27}$ Regardless of race, in other words, the likelihood of pretrial detention was greater for males, for unmarried offenders, for offenders whose criminal history and offense seriousness scores were larger, and for offenders adjudicated in the Southern District of Iowa.

Table 3: Logistic Regression Results: Data Partitioned by Offender Race

\begin{tabular}{|c|c|c|c|c|c|c|}
\hline \multirow[t]{2}{*}{ Variables } & \multicolumn{3}{|c|}{ Black Offenders } & \multicolumn{3}{|c|}{ White Offenders } \\
\hline & $b$ & SE & Odds & $b$ & SE & Odds \\
\hline Offender's Sex (male) & $1.19^{*}$ & .35 & 3.27 & $.67^{*}$ & .24 & 1.95 \\
\hline Offender's Age & .01 & .02 & 1.01 & -.01 & .01 & 0.99 \\
\hline \multicolumn{7}{|c|}{ Indicators of Dangerousness } \\
\hline $\begin{array}{l}\text { Prior Drug Trafficking } \\
\text { Conviction }\end{array}$ & -.16 & .28 & 0.86 & .35 & .25 & 1.42 \\
\hline $\begin{array}{l}\text { Use of a Weapon During } \\
\text { Offense }\end{array}$ & .27 & .32 & 1.31 & .06 & .23 & 1.06 \\
\hline $\begin{array}{l}\text { Under Criminal Justice } \\
\text { Control }\end{array}$ & $.57^{*}$ & .28 & 1.76 & .36 & .22 & 1.43 \\
\hline
\end{tabular}

Indicators of Stakes in Conformity

$\begin{array}{llllllll}\text { Education } & & & & & & & \\ \text { No High School Degree } & .56 & .36 & 1.75 & .62^{*} & .30 & 1.86\end{array}$

27. I used the following formula to calculate $\mathrm{z}$-tests for the equality of regression coefficients: $\mathrm{z}$ $=\mathrm{b}_{1}-\mathrm{b}_{2} / \mathrm{Sqrt}\left(\mathrm{SEb}_{1}{ }^{2}+\mathrm{SEb}_{2}{ }^{2}\right)$. Raymond Paternoster et al., Using the Correct Statistical Test for the Equality of Regression Coefficients, 36 CRIMINOLOGY 859, 862 (1998). 


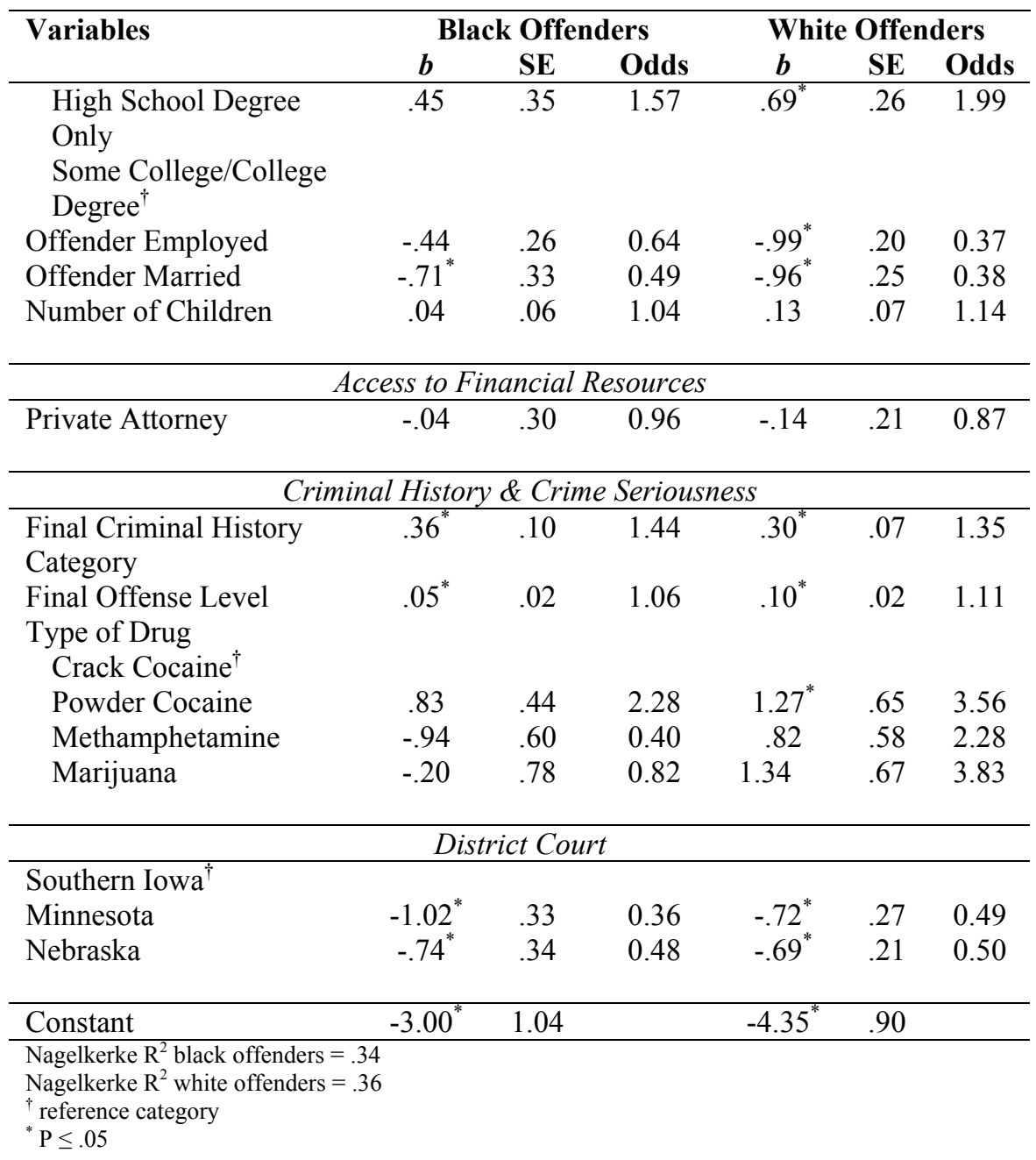

Several variables do exert differential effects on the likelihood of pretrial detention for black offenders and for white offenders. Of particular interest is the fact that being under the control of the criminal justice system has a significant positive effect on pretrial detention for blacks only. Black offenders - but not white offenders - who were on probation or parole or who were out on bond at the time of the offense faced higher odds of pretrial detention. On the other hand, employment and education affected detention for white offenders but not for black offenders. Among whites, being employed or having some college or a college degree reduced the odds of pretrial detention. Thus, the aggravating effect of being under the control of the criminal justice 
system is confined to black offenders and the mitigating effects of employment and education are found for white offenders only.

\section{B. Pretrial Detention and Sentence Length}

The results presented in Table 2 reveal that the race and sex of the offender have significant direct effects on the likelihood of pretrial detention. In these three U.S. District Courts, black offenders are more likely than white offenders - and male offenders are more likely than female offenders - to be held in custody prior to the sentencing hearing. To determine whether the race and sex of the offender have indirect and/or cumulative effects on sentence severity through their effects on pretrial detention, I estimated a model of sentence length, controlling for the offender's pretrial status and for the offender and case characteristics identified by prior research as predictors of sentences imposed under the federal sentencing guidelines. ${ }^{28}$

The results of the OLS regression analysis of the length of the prison sentence (see Table 4) reveal that pretrial status does affect sentence length, net of the presumptive sentence, whether the offender received a downward or substantial assistance departure, and whether the offender pled guilty, all of which are the strongest predictors of sentence length. Offenders who were in custody at the time of the sentence hearing received sentences that averaged almost eight months $(b=7.95)$ longer than those imposed on offenders who were not detained before the hearing. Other significant predictors of sentence length include the offender's sex (female offenders received shorter sentences than male offenders), the offender's marital status (married offenders received longer sentences than those who were not married), and the district in which the case was adjudicated (offenders sentenced in Minnesota and Nebraska received shorter sentences than those sentenced in Southern Iowa). The race of the offender, on the other hand, did not affect the length of the sentence.

28. See generally Albonetti, Sentencing, supra note 2; Albonetti, Joint Conditioning Effect, supra note 2; Mustard, supra note 2; Spohn, supra note 2; Stacey \& Spohn, supra note 2; Johnson et al., supra note 18. 
Table 4: OLS Regression Results: Length of the Prison Sentence

\begin{tabular}{|c|c|c|c|}
\hline Variables & b & Beta & T-Value \\
\hline Pretrial Status (in custody) & 7.95 & .05 & $2.93^{*}$ \\
\hline Offender's Race (black) & -1.59 & -.01 & -0.34 \\
\hline Offender's Sex (female) & -9.52 & -.05 & $-3.03^{*}$ \\
\hline Offender's Age & 0.13 & .01 & 0.81 \\
\hline \multicolumn{4}{|c|}{ Indicators of Dangerousness } \\
\hline Prior Drug Trafficking Conviction & 2.84 & .02 & 1.00 \\
\hline Use of a Weapon During Offense & -2.76 & -.01 & -0.94 \\
\hline Under Criminal Justice Control & 0.65 & .004 & 0.25 \\
\hline \multicolumn{4}{|c|}{ Indicators of Stakes in Conformity } \\
\hline \multicolumn{4}{|l|}{ Education } \\
\hline No High School Degree & 1.49 & .01 & 0.41 \\
\hline High School Degree Only & 1.99 & .01 & 0.59 \\
\hline Some College/College Degree ${ }^{\dagger}$ & & & \\
\hline Offender Employed & -4.02 & -.02 & -1.58 \\
\hline Offender Married & 6.10 & .03 & $1.99^{*}$ \\
\hline Number of Children & -0.29 & -.006 & -0.39 \\
\hline \multicolumn{4}{|c|}{ Access to Financial Resources } \\
\hline Private Attorney & -1.82 & -.01 & -0.68 \\
\hline \multicolumn{4}{|c|}{ Case Characteristics } \\
\hline Presumptive Sentence & 0.67 & .74 & $43.22^{*}$ \\
\hline Downward Departure & -27.88 & -.10 & $-6.79^{*}$ \\
\hline Substantial Assistance Departure & -55.01 & -.33 & $-21.35^{*}$ \\
\hline Guilty Plea & -30.64 & -.09 & $-5.94^{*}$ \\
\hline \multicolumn{4}{|l|}{ Type of Drug } \\
\hline \multicolumn{4}{|l|}{ Crack Cocaine ${ }^{\dagger}$} \\
\hline Powder Cocaine & -3.28 & -.01 & -0.66 \\
\hline Methamphetamine & -6.22 & -.04 & -1.25 \\
\hline Marijuana & -9.71 & -.03 & -1.50 \\
\hline \multicolumn{4}{|c|}{ District Court } \\
\hline \multicolumn{4}{|l|}{ Southern Iowa ${ }^{\dagger}$} \\
\hline Minnesota & -15.60 & -.08 & $-4.83^{*}$ \\
\hline Nebraska & -12.15 & -.07 & $-4.30^{*}$ \\
\hline Constant & 71.91 & & 7.16 \\
\hline \multicolumn{4}{|l|}{ Nagelkerke $\mathrm{R}^{2}=.79$} \\
\hline \multicolumn{4}{|l|}{${ }^{\dagger}$ reference category } \\
\hline${ }^{*} \mathrm{P} \leq .05$ & & & \\
\hline
\end{tabular}


Analysis of the data partitioned by the race of the offender (results not shown) revealed that the sentence penalty for pretrial detention imposed on black offenders (10.48 months) was somewhat larger than the penalty imposed on white offenders (6.27 months); however, the Ztest for equality of regression coefficients revealed that this difference was not statistically significant $(Z=0.62)$. Pretrial detention, then, had a similar negative effect on sentences for both black offenders and white offenders. Analysis of the data partitioned by the sex of the offender (results not shown) revealed that whereas pretrial detention did not result in harsher sentences for female offenders, it produced an increase of 8.35 months for male offenders.

\section{The Interaction of Offender Race and Sex}

The results discussed thus far reveal that the race and the sex of the offender affected the likelihood of pretrial detention in the full model and that the sex of the offender affected the odds of pretrial detention for both black offenders and white offenders. To further explore this issue and to test for interaction between the race of the offender, the sex of the offender, and pretrial status, I created four dummy variables measuring the combination of offender race and offender sex: black male, white male, black female, and white female. I then re-ran the analysis of pretrial detention, substituting these variables for the original race and sex variables. To determine whether black males were singled out for the harshest treatment, I ran the analysis with black males as the reference category. To determine whether the more lenient treatment of females was confined to white females, I re-estimated the model with, first, white females as the reference category and, then, black females as the reference category.

The results of these analyses are displayed in Table 5. Consistent with prior research on sentence outcomes in state courts, ${ }^{29}$ the likelihood of pretrial custody was substantially higher for black male offenders than for other offenders. The odds of pretrial detention for black males were twice those for white males, and the differences between black males and either black females or white females were even larger. In fact, as shown in the second and third panels of Table 4, black males were 3.7 times

29. See generally Darrell Steffensmeier et al., The Interaction of Race, Gender, and Age in Criminal Sentencing: The Punishment Cost of Being Young, Black, and Male, 36 CRIMINOLOGY 763 (1998); Cassia Spohn \& David Holleran, The Imprisonment Penalty Paid by Young, Unemployed Black and Hispanic Male Offenders, 38 CRIMINOLOGY 281 (2000). 
more likely than white females and three times more likely than black females to be held in custody before sentencing. There also were large differences between white females and white males (odds $=1.88$ ), but the difference between white females and black females was not statistically significant. Thus, black males were singled out for the harshest treatment, but white females were not treated any differently than black females.

Table 5: Results of the Logistic Regression Analysis: Race $\mathrm{x}$ Sex Interactions and Pretrial Detention ${ }^{\dagger}$

\begin{tabular}{lccc}
\hline Variables & \multicolumn{1}{c}{$\boldsymbol{b}$} & SE & Odds \\
\hline \multicolumn{4}{c}{ Race $x$ Sex: Black Male as Reference Category } \\
\hline White Male & $-0.68^{*}$ & .31 & 0.51 \\
Black Female & $-1.11^{*}$ & .34 & 0.33 \\
White Female & $-1.31^{*}$ & .33 & 0.27 \\
& \multicolumn{4}{c}{} \\
\hline \multicolumn{5}{c}{ Race $x$ Sex: White Female as Reference Category } \\
\hline Black Male & $1.31^{*}$ & .33 & 3.71 \\
White Male & $0.63^{*}$ & .23 & 1.88 \\
Black Female & 0.20 & .43 & 1.22 \\
& & & \\
\hline \multicolumn{5}{c}{ Race $x$ Sex: Black Female as Reference Category } \\
\hline Black Male & $1.11^{*}$ & .34 & $3.03^{*}$ \\
White Male & 0.43 & .42 & 1.54 \\
White Female & -0.20 & .43 & 0.82 \\
\hline
\end{tabular}

${ }^{\dagger}$ All of the independent variables included in Table 2 are included in the analysis.

${ }^{*} \mathrm{P} \leq .05$

I also investigated the possibility of interaction between the race of the offender, the sex of the offender, and sentence length. These results, which are shown in Table 6, illustrate the importance of considering the joint influence of these background characteristics. Recall from Table 4 that the sex, but not the race, of the offender affected sentence length. Based on these findings alone, it would have been reasonable to conclude that black offenders were treated no differently than white offenders and that female offenders were treated more leniently than male offenders. These conclusions, while accurate, would have been misleading. As shown in Table 6 , black male offenders were not treated differently than white offenders: black males received substantially longer sentences than black females, but there were no differences between the sentences imposed on black male offenders and either white male offenders or 
white female offenders. However, panel 3 of Table 6 reveals that there were large and statistically significant differences in the sentences imposed on black female offenders and each of the other categories of offender race and sex. The sentences imposed on black females were more than twenty-two months shorter than those imposed on black males, more than twenty months shorter than those imposed on white males, and about sixteen months shorter than those imposed on white females. Table 6 also reveals that white females were treated no differently than black males or white males. The statistically insignificant effect for the race of the offender, in other words, masked the more lenient treatment of black females, and the statistically significant effect for the sex of the offender masked the fact that the more lenient treatment of female offenders was confined to black females. Stated another way, the effect of race was conditioned by sex and the effect of sex was conditioned by race.

Table 6: Results of the OLS Regression Analysis: Race x Sex Interactions and Sentence Length ${ }^{\dagger}$

\begin{tabular}{|c|c|c|c|}
\hline Variables & b & Beta & T-value \\
\hline \multicolumn{4}{|c|}{ Race x Sex: Black Male as Reference Category } \\
\hline White Male & -2.23 & -.01 & -0.45 \\
\hline Black Female & -22.59 & -.06 & $-4.01^{*}$ \\
\hline White Female & -6.38 & -.04 & -1.18 \\
\hline \multicolumn{4}{|c|}{ Race $x$ Sex: White Female as Reference Category } \\
\hline Black Male & 6.38 & .04 & 1.18 \\
\hline White Male & 4.15 & .02 & 1.13 \\
\hline Black Female & -16.21 & -.04 & $-2.30^{*}$ \\
\hline \multicolumn{4}{|c|}{ Race $x$ Sex: Black Female as Reference Category } \\
\hline Black Male & 22.59 & .13 & $4.01^{*}$ \\
\hline White Male & 20.36 & .12 & $3.01^{*}$ \\
\hline White Female & 16.21 & .08 & $2.30^{*}$ \\
\hline
\end{tabular}

${ }^{\dagger}$ All of the independent variables included in Table 2 are included in the analysis.

${ }^{*} \mathrm{P} \leq .05$

\section{DISCUSSION AND CONCLUSION}

Research exploring the effects of race and sex on the treatment of offenders in U.S. District Courts has focused almost exclusively on sentence outcomes and downward departures. This research concludes 
that being held in custody prior to trial leads to longer sentences and a lower likelihood of receiving a downward departure. In fact, in studies that include a control for pretrial status, this variable emerges as one of the strongest predictors of sentence severity in the federal system. The purpose of this study was to extend prior research by investigating the factors that influence the likelihood of pretrial detention for offenders charged with drug trafficking in three U.S. District Courts. More specifically, the intent was to determine whether the race and sex of the offender affected the odds of pretrial detention and to explore the possibility of indirect and cumulative race and sex effects on sentence severity.

The results of the analysis revealed that the offender's pretrial status was predicted by a mix of offender and case characteristics. The odds of pretrial detention were higher for offenders whose crimes and criminal histories were more serious and for offenders who were under some form of criminal justice system control at the time of the offense. Pretrial status also was affected by offenders' stakes in conformity and community ties: pretrial detention was less likely for offenders who were more educated, offenders who were employed, and offenders who were married. These findings are not surprising, given the criteria that judges are legally permitted to consider in determining whether to release or detain the offender. Among the factors identified as relevant by $\S$ $3142(\mathrm{~g})$ of the Bail Reform Act of 1984 are the nature of the offense, the offender's past conduct and current legal status, the offender's financial resources, and the offender's family ties, employment, and community ties. With the exception of financial resources (as measured by the type of attorney who represented the offender), these were the exact factors that determined whether the offender would be detained in these three district courts.

I also found, however, that pretrial detention was affected by the offender's race and sex: black offenders were more likely than white offenders, and male offenders were more likely than female offenders, to be held in custody prior to the sentencing hearing. These findings may reflect judges' interpretation and application of the criteria set forth in the Bail Reform Act. Although the statute does not, of course, allow judges to consider the offender's race or sex, it does permit them to take the offender's dangerousness into consideration when deciding between pretrial release and detention. If, as prior research has shown, ${ }^{30}$ judges

30. See generally Sara Steen, Rodney L. Engen, \& Randy R. Gainey, Images of Danger and Culpability: Racial Stereotyping, Case Processing, and Criminal Sentencing, 43 CRIMINOLOGY 435 (2005); Spohn \& Sample, supra note 5. 
stereotype black drug traffickers and male drug traffickers as more dangerous and threatening than whites or females engaged in drug trafficking, their interpretation of the legally relevant criteria may lead to higher rates of pretrial detention for black offenders and for male offenders. The validity of this explanation is confirmed by the finding that being under the control of the criminal justice system increased the odds of pretrial detention for blacks but not for whites and that being employed or having more education decreased the likelihood of detention for whites but not for blacks. This suggests that judges do, in fact, interpret the legally relevant criteria set forth in the bail statute in ways that disadvantage black offenders.

The second objective of this study was to explore the possibility of indirect and cumulative effects of race and sex on sentence severity. Given prior research showing that pretrial status was an important predictor of sentence outcomes, I wanted to investigate whether the race and sex of the offender operated through pretrial status to produce harsher sentences for black offenders and for male offenders. I found that the race of the offender had a direct effect on pretrial status and an indirect effect on sentence severity through its effect on pretrial status, but did not have a direct effect on sentence severity. Black defendants were more likely than white defendants to be detained, and defendants who were detained received longer sentences than those who were not detained. I also found that the sex of the defendant had a direct effect on pretrial status, a direct effect on sentence length, and an indirect effect on sentence length through its effect on pretrial status. In other words, male defendants experienced cumulative disadvantage: they were more likely than female defendants to be held in custody before sentencing (which increased the sentences that judges imposed) and they received longer sentences than female offenders, net of their pretrial status.

The results of the analyses using the dummy variables for the race and sex of the offender suggest a more complex set of relationships. These relationships are diagrammed in Figure 1 and discussed below. Turning first to the results for pretrial detention, I found that black male offenders were more likely than all other offenders to be held in custody prior to trial and that white female offenders faced lower odds of pretrial detention than did white male offenders. With respect to sentence length, I found that black female offenders faced substantially shorter sentences than all other offenders. For male offenders, then, race had a direct effect on pretrial detention (black males were more likely to be detained than white males) and an indirect effect on sentence length through its effect on pretrial detention, but no direct effect on sentence severity (black males were not sentenced differently than white males). 
For female offenders, race did not have a direct effect on pretrial detention (black females did not face different odds of pretrial detention than white females) and pretrial detention did not affect sentence severity, but race did directly affect sentence length (black females received shorter sentences than white females). For black offenders, sex had a direct effect on pretrial detention (black males were more likely than black females to be detained), an indirect effect on sentence through its effect on pretrial detention, and a direct effect on sentence severity (black males got longer sentences than black females). For white offenders, sex had a direct effect on pretrial detention (white males were more likely to be detained than white females), an indirect effect on sentence severity through its effect on pretrial detention, but no direct effect on sentence severity (white males did not receive different sentences than white females).

Figure 1: The Direct, Indirect, and Cumulative Effects of Offenders' Race and Sex on Sentence Severity

Male Offenders

Female Offenders
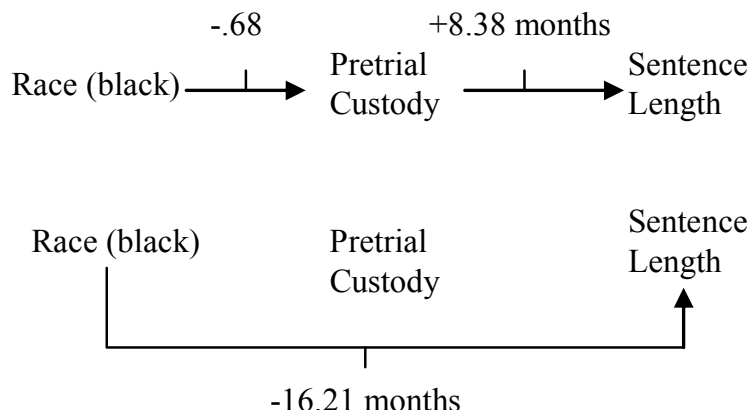

-16.21 months

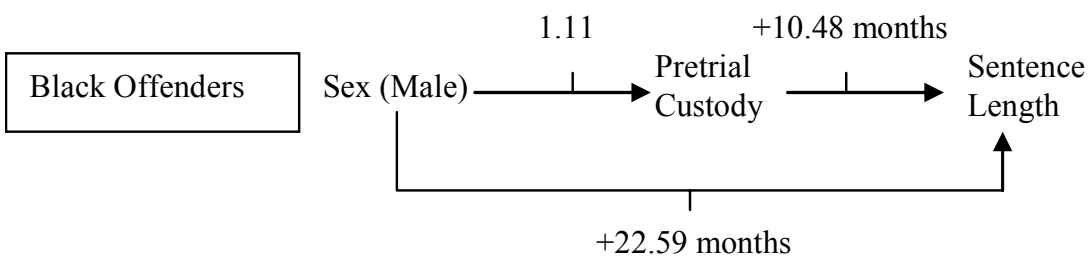

+22.59 months

White Offenders

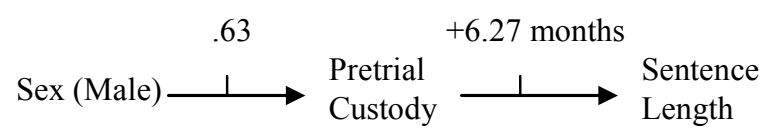


These findings illustrate the importance of moving beyond models that focus exclusively on the direct effects of legally irrelevant offender characteristics and of testing for the interaction between the offender's race and sex. As Zatz stated more than twenty years ago, "research that tests only for main effects (i.e., overt bias) and does not investigate all of the possible manifestations of discrimination may erroneously conclude that discrimination does not exist when, in fact, it does."

31. Marjorie S. Zatz, The Changing Forms of Racial/Ethnic Biases in Sentencing, 24 J. RES. CRIME \& DELINQ. 69, 83 (1987). 